In the Shadow of FDR 
Flood Control Politics

The Perils of Prosperity, 1914-32

Franklin D. Roosevelt and the New Deal, 1932-1940

New Deal and Global War

The Great Age of Change

Franklin D. Roosevelt: A Profile

The New Deal: A Documentary History

The Growth of the American Republic, with Samuel Eliot Morison and Henry Steele Commager

A Troubled Feast

The Supreme Court Reborn

The FDR Years

American Places

The White House Looks South

Herbert Hoover 


\section{In the Shadow of}

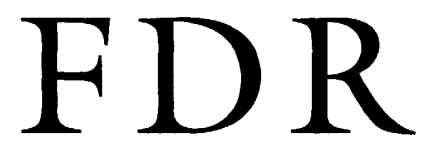

FROM HARRY TRUMAN TO BARACK OBAMA

William E. Leuchtenburg

Fourth Edition

Cornell University Press

ITHACA AND LONDON 


\section{Copyright $(9) 1983$ by Cornell University Press}

Revised and updated and new text copyright (C 1985, 1989, 1999, 2001, 2009 by Cornell University

All rights reserved. Except for brief quotations in a review, this book, or parts thereof, must not be reproduced in any form without permission in writing from the publisher. For information, address Cornell University Press, Sage House, 512 East State Street, Ithaca, New York 14850.

First published 1983 by Cornell University Press First printing, fourth edition, 2009

Printed in the United States of America

\section{Library of Congress Cataloging-in-Publication Data}

\section{Leuchtenburg, William Edward, I922-}

In the shadow of FDR : from Harry Truman to Barack Obama / William E. Leuchtenburg. - 4th ed., rev. and updated.

p. $\mathrm{cm}$.

Includes bibliographical references and index.

ISBN 978-0-80I4-4855-3 (cloth : alk. paper)

ISBN 978-0-80I4-7568-9 (pbk.: alk. paper)

I. United States-Politics and government-1945-1989. 2. United StatesPolitics and government-1989- . 3. Roosevelt, Franklin D. (Franklin Delano), 1882-1945-Influence. 4. Presidents-United States-History-2oth century.

I. Title. II. Title: In the shadow of Franklin Delano Roosevelt.

E743.L49 2009

973.9-dc22 2009037865

Cornell University Press strives to use environmentally responsible suppliers and materials to the fullest extent possible in the publishing of its books. Such materials include vegetable-based, low-VOC inks and acid-free papers that are recycled, totally

chlorine-free, or partly composed of nonwood fibers. For further information, visit our website at www.cornellpress.cornell.edu.

I 3579 Cloth printing I0 8642

I 3579 Paperback printing Io 8642 